E-ISSN : 2549-6581

OPEN ACCESS

Journal of Issues in

Artikel Hasil Penelitian

Diterima : 2 Maret 2018

Direview : 4 Maret 2018

Dimuat : April - Juli 2018

Midwifer

\title{
Studi Kasus: Kehamilan dengan dengan Katub Jantung Prostetik Mekanik dan Penggunaan Antikoagulan
}

The Use of Mechanical Heart Valves and Anticoagulation during Pregnancy

Anin Indriani ${ }^{1 *}$, Bambang Rahardjo1,2, Cholid Tri Tjahjono³

1Program Studi Magister Kebidanan Fakultas Kedokteran Universitas Brawijaya

2Divisi Fetomaternal Program Studi Obstetri dan Ginekologi Fakultas Kedokteran Universitas Brawijaya

3Program Studi Jantung dan Pembuluh Darah Fakultas Kedokteran Universitas Brawijaya

Email* : anin.indr@gmail.com

HP : 08133338-0407

\begin{abstract}
Women who have prosthetic heart valves, pregnancy is risky for mother and fetus. Heparin has been considered safer for the fetus than warfarin, but may not provide adequate anticoagulation for the mother. Women with mechanical valves have higher rates of fetal loss and maternal complications. In our study, we report the treatment for anticoagulation in a pregnant woman (39 years old) that underwent artificial mitral valve replacement 2 years prior to her pregnancy. Until she became pregnant warfarin was administered for anticoagulation. At gestational week 5 she developed treatened abortion. At gestational week 22-24 our patient developed asthma bronkhiale attack. She recovered uneventfully and gave birth to a healthy child at gestational week 38. In addition to our case presentation we review the sparse evidence in the literature regarding anticoagulation in pregnant women with mechanical heart valves and discuss the rational of different anticoagulation regimens with regards to maternal and fetal outcome. Warfarin was effective in preventing thromboembolism in the mothers, and it did not show a significant impact on the babies. Special consideration is directed towards UFH administration as an alternative to oral anticoagulation during delivery preparation.
\end{abstract}

Key words: pregnancy, anticoagulant, mechanical prosthetic heart valves, warfarin, heparin

\section{ABSTRAK}

Wanita yang menggunakan katub jantung prostetik mekanik yang mengalami kehamilan, sangat berresiko terhadap ibu dan janin. Heparin sangat aman bagi janin dibandingkan warfarin, namun memiliki efek antikoagulasi yang lebih rendah dibandingkan warfarin. Studi kasus ini melporkan seorang wanita 39 tahun dengan katub jantung prostetik mekanik yang mengalami kehamilan setelah 2 tahun pemakaian. Selama kehamilan penderita menggunakan antikoagulan 
warfarin. pada usia kehamilan 5 minggu psien mengalami abortus iminens namun bisa diatasi. Pada usia kehamilan 22-24 minggu pasien mengalami serangan asma namun dapat mengalami rekoveri. Selanjutnya pasien menentukan cara persalinan perabdominam pada usia kehamilan 38 minggu. Hasil akhir dari tatalaksana yang digunakan, didapatkan outcome yang baik terhadap ibu maupun janin. Tidak didapatkan tanda-tanda embriopati akibat penggunaan warfarin pada trimester pertama. Dari studi kasus ini juga tampak bahwa warfarin cukup efektif untuk mencegah terjadinya tromboemboli pada ibu, dan pemakaian UFH dapat digunakan sebagai alternatif untuk persiapan persalinan.

Kata kunci: kehamilan, antikoagulan, katub jantung prostetik mekanik, warfarin, heparin

Korespondensi: Anin Indriani. Surel: anin.indr@gmail.com 


\section{PENDAHULUAN}

Berbagai jenis katub jantung prostetik diimplantasikan pada remaja wanita tiap tahunnya di seluruh dunia yang sebagian besar merupakan akibat penyakit jantung reumatik dan congenital heart disease. Cepat atau lambat, tentu saja diantara mereka akan mengalami suatu kehamilan. Konseling pre-konsepsi diikuti dengan monitoring dan terapi saat kehamilan merupakan suatu tantangan tersendiri bagi seorang kardiologis yang merawat seorang wanita muda ${ }^{1}$. Sedangkan bagi seorang dokter kandungan akan lebih sering menghadapi suatu kasus kehamilan dengan katub jantung prostetik.

Katub jantung prostetik mekanik, katub jantung bioprostesis dan kelainan katub jantung bawaan, masing-masing memiliki resiko spesifik selama kehamilan. Konseling pre-konsepsi diikuti dengan monitoring dan terapi saat kehamilan merupakan suatu tantangan tersendiri bagi seorang kardiologis yang merawat seorang wanita muda dengan penyakit katub jantung ${ }^{1}$.

Kehamilan pada wanita dengan katub jantung prostetik, merupakan hal yang sangat berresiko bagi ibu dan janin. Ashour ZA et al, 2000, melaporkan adanya 100 kehamilan pada 67 wanita dengan katub jantung mekanik (dengan usia antara $19-45$ tahun). Dari penelitian tersebut didapatkan kejadian fetal loss sebanyak 44 kasus dengan penyebab abortus spontan (28 kasus), kematian janin intrauteri (4 kasus), stillbirth (3 kasus), kematian neonatal (1 kasus), persalinan prematur (2 kasus), inkompatibilitas rhesus (2 kasus) dan kematian maternal (4 kasus) ${ }^{2}$.

Managemen kehamilan dengan katub jantung prostetik merupakan permasalahan pelik bagi semua institusi kesehatan, terutama mengenai keselamatan ibu dan bayi. Komplikasi meningkat seiring dengan perubahan hemodinamik dan perubahan fisiologis jantung yang terjadi selama kehamilan.
Penggunaan

obat-obatan

kardiovaskular (terutama antikoagulan)

dapat menyebabkan berbagai

komplikasi bagi janin dan ibu.

Disamping itu, kehamilan

menyebabkan suatu kondisi

hiperkoagulasi sehingga dapat meningkatkan kejadian tromboemboli ${ }^{3}$.

Manajemen yang baik pada kehamilan dengan katub jantung prostetik mekanik terbukti dapat meningkatkan prognosis baik ibu maupun janin, akan tetapi bukan berarti tanpa resiko. Dokter dan pasien harus siap dengan berbagai komplikasi yang mungkin terjadi. Diperlukan edukasi yang baik bagi pasien sebelum memutuskan untuk hamil, sehingga komplikasi yang mungkin terjadi dalam kehamilan dapat dipantau dengan ${ }^{4}$. Dalam laporan kasus ini kami laporkan kasus seorang ibu hamil dengan katub jantung prostetik mekanik dengan harapan dapat menambah pengetahuan dan menjadi referensi dalam penatalaksanaan kehamilan dengan katub jantung prostetik.

\section{Case Report}

Seorang wanita 39 tahun dengan mengalami kelainan pada katub jantung mitral dan katub trikuspid sejak usia 36 tahun, yang selanjutnya memakai katub jantung prostetik mekanik dan menjalani prosedur bedah katub trikuspid dengan prosedur De Vega. Penderita menjalani operasi penggantian katub mitral dengan St. Jude Mekanik no. 33 (17 jahitan pledget). Penderita juga memiliki riwayat penyakit lain yakni asma bronkhiale yang diderita sejak kecil. Kehamilan ini merupakan kehamilan ketiga, dengan riwayat persalinan sebelumnya 2 kali menjalani persalinan normal.

Pasien memiliki keluhan awal berupa sesak saat beraktifitas yang dirasakan semakin lama semakin memberat bahkan muncul pada saat istirahat. Pasien menjalani operasi penggantian katub jantung pada tanggal 8 November 2012 di Rumah 
Sakit Jantung dan Pembuluh Darah Harapan Kita Jakarta. Setelah operasi pasien kontrol teratur ke dokter ahli jantung, dan mendapatkan terapi warfarin (simarc $\AA)$ yang diminum secara teratur $1 \times 2 \mathrm{mg}$ pada malam hari.

Penderita mengalami kehamilan setelah 2 tahun pasca pemasangan katub jantung mekanik prostetik. Penderita baru menyadari kehamilannya tersebut saat usia kehamilan 5 minggu. Kehamilan tersebut diketahui dengan tidak sengaja karena mengalami abortus iminens. Selama mengalami abortus iminen penderita disarankan untuk bedrest serta mendapatkan terapi tokolitik dan asam folat. Selama kehamilan selanjutnya pasien tidak memiliki keluhan sesak saat beraktifitas maupun saat istirahat, dan rutin melakukan pemeriksaan jantung di Poli Penyakit Jantung dan Pembuluh Darah RSUD dr Saiful Anwar Malang sebulan sekali. Pasien secara terjadwal melakukan pemeriksaan faal hemostasis. Gambar 1 menunjukkan hasil pemeriksaan ultrasonography (USG) kehamilan pada trimester 1 yakni pada saat penderita mengalami abortus iminens. Dari pemeriksaan tersebut didapatkan gestasional sacc intrauterin tunggal dengan ukuran $1,81 \mathrm{~cm}$ (6 weeks 1 day).

Selama kehamilan senantiasa dilakukan pemeriksaan antenatal secara rutin baik oleh bagian kebidanan. Pemeriksaan antenatal terutama untuk mencariadanya kemungkinan kelainan kongenital pada janin.

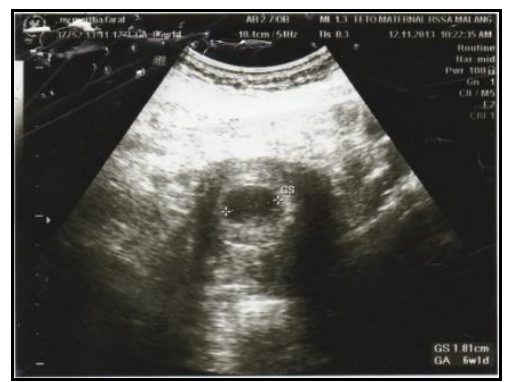

\section{Gambar 1. Pemeriksaan USG kehamilan saat pasien datang pertamakali.}

Antikoagulan diberikan secara peroral selama kehamilan termasuk pada saat trimester 1 dengan target INR (international normalised ratio) pada 2,5-3,5. Pada kehamilan ini dosis warfarin dipantau terus menerus untuk menjaga target INR. INR diperiksa setiap sebulan sekali.

Dalam studi kasus ini, pada usia kehamilan 6 minggu, pasien telah ditawarkan untuk dilakukan penggantian warfarin dengan pemberian heparin. Namun pasien menolak dengan alasan pemberian heparin harus rawat inap di rumah sakit. Akan tetapi telah diberikan edukasi yang baik mengenai resiko yang mungkin timbul akibat pemberian warfarin pada usia kehamilan 6 minggu. Oleh sebab itu, diputuskan untuk memberikan warfarin dosis rendah yakni 2-4 mg/hari.

Gambar 2 menunjukkan hasil pemeriksaan status kardiologi saat penderita pertamakali datang. Hasil pemeriksaan status kardiologi menunjukkan fungsi dan letak mechanical mitral valve baik serta tidak tampak thrombus.

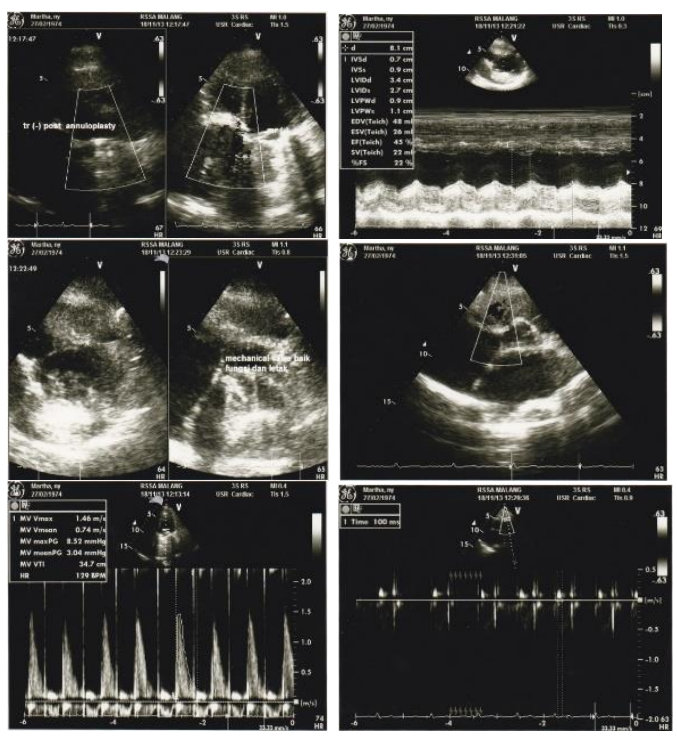




\section{Gambar 2. Pemeriksaan echocardiography datang pertamakali. \\ saat}

Penatalaksaan penderita ini dilakukan dengan membentuk tim yang terdiri dari bagian obstetri-ginekologi, anak, kardiologi, paru, dan anestesi. Melalui hasil konferensi yang dilakukan, tim menyimpulkan bahwa penderita memiliki jantung dengan functional class I-II. Jika proses persalinan terbaik adalah pervaginam, maka sebaiknya menggunakan prosedur painless labor. Penderita tidak memiliki kontraindikasi untuk mengejan selama persalinan, namun dengan resiko perdarahan pada proses persalinan baik pervaginam maupun perabdominam terkait dengan penggunaan antikoagulan. Pemberian warfarin sebaiknya dihentikan minimal 48 jam sebelum persalinan, dan diganti dengan pemberian heparin. Jika selama kehamilan didapatkan suatu indikasi obstetri sehingga harus dilakukan terminasi kehamilan segera, sebaiknya dengan back-up ruangan CVCU selama 24 jam setelah tindakan terminasi.

Pemeriksaan fetal dilakukan secara rutin untuk mengetahui kesejahteraan janin dalam rahim. Ultrasonografi skrining dilakukan pada trimester 1 untuk mendeteksi dini adanya kelainan kongenital terutama terkait dengan penggunaan antikoagulan.

Pada saat usia kehamilan 22-24 minggu, pasien mengalami asma attack, diberikan terapi ceftriaxone 2x 1 gr iv, dexametason $3 \times 5$ mg,dan diberikan nebulizer (Combivent 4x sehari dan Pulmicort $4 x$ sehari). Selanjutnya pasien diberikan terapi Berotec(C) spray $3 \times 1$ 9jika perlu), dan metil prednisolon $3 \times 4 \mathrm{mg}$.

Proses persalinan, penderita memutuskan untuk dilakukan SC elektif pada usia kehamilan 38-39 minggu diikuti dengan prosedur Tubektomi. Enam hari sebelum persalinan warfarin dihentikan dan diberikan heparin bolus $60 \mathrm{lU} / \mathrm{kgBB}$ (dimulai dengan $1950 \mathrm{IU}$
$0,4$ cc $(5000 / \mathrm{cc}))$ dilanjutkan dengan

drip heparin unfraksional 12

IU/kgBB/jam (20.000 dalam NS 500 cc 20,6 cc/jam 825 IU/jam) dengan target activated partial thromboplastin time (APTT) 50 - 70 detik atau 1,5 $2 x$ dari nilai kontrol. Obat antikoagulanoral diberikan 24 jam setelah persalinan dan pasien menjalani rawat inap sampai dengan INR pada rentang terapi.

\section{PEMBAHASAN}

Kehamilan menyebabkan perubahan anatomi, fisiologis dan biokimia pada ibu hamil. Pada pasien dengan penyakit katub jantung yang telah menjalani koreksi dengan pemasangan katub jantung prostetik akan memiliki beberapa permasalahan khusus Resiko terjadinya komplikasi pada wanita hamil dengan katub jantung prostetik bersifat multifaktorial. Hal tersebut berkaitan dengan peningkatan volume hemodinamik, status hiperkoagulasi pada kehamilan dan resiko penggunaan antikoagulan terhadap fetus. Perlu diperhatikan bahwa perubahan bermakna terhadap faktor-faktor pembekuan akan meningkatkan resiko trombosis selama kehamilan. Trombosis pada katub jantung prostetik telah banyak dilaporkan akibat pemberian antikoagulan yang tidak adekuat ${ }^{5}$

$$
\text { Perubahan fisiologis yang }
$$

terjadi pada kehamilan, yang mempengaruhi katub jantung prostetik terutama adalah karena adanya perubahan hemodinamik dan perubahan status koagulasi selama kehamilan. Pada wanita normal, volume darah rata-rata pada atau menjelang aterm adalah $50 \%$ lebih tinggi daripada volume pada keadaan tidak hamil. Volume darah ibu mulai meningkat selama trimester pertama, meningkat paling pesat pada trimester kedua, dan kemudian meningkat dengan kecepatan jauh lebih lambat pada trimester ketiga hingga mendatar pada beberapa minggu terakhir kehamilan 6 . 
Pada laporan kasus ini, tidak didapatkan komplikasi yang disebabkan oleh faktor kehamilan. Komplikasikomplikasi mayor yang dapat terjadi pada pengguna katub jantung prostetik dengan kehamilan. Peningkatan hemodinamik akibat kehamilan dapat menyebabkan terjadinya gagal jantung jika didapatkan trombosis katub jantung, stenosis, regurgitasi, atau terjadi patient-prosthesis mismatch. Evaluasi klinis dan transesophageal echocardiography (TEE) sebelum kehamilan harus dilakukan untuk menentukan fungsi katub dan hemodinamik yang tidak normal sehingga dapat terjadi komplikasi, serta dapat mengidentifikasi disfungsi yang membutuhkan perawatan. Disamping itu, terdapat peningkatan resiko trombosis katub pada wanita hamil dengan katub jantung mekanik yang disebabkan adanya kondisi hiperkoagulasi. Pemeriksaan transthoracic echocardiography (TTE) dasar bermanfaat sebagai acuan standar pada pasien jika dicurigai terjadi trombosis katub ${ }^{7}$.

Resiko dan komplikasi pada pasien dengan katub jantung prostetik selama kehamilan selain dipengaruhi oleh faktor pasien (profil kapasitas jantung terkait kehamilan), jenis prostetik yang digunakan juga sangat berpengaruh ${ }^{8}$.

Penderita dalam laporan kasus ini telah menjalani operasi penggantian katub mitral dengan St. Jude Mekanik no. 33 (17 jahitan pledget). Selama kehamilan tidak didapatkan komplikasi akibat katub jantung prostetik mekanik yang digunakan.

Katub jantung prostetik dapat menyebabkan komplikasi berupa tromboemboli, perdarahan, endokarditis, disfungsi katub, operasi ulang (pada bioprostetik) atau kematian. Resiko-resiko tersebut dapat dialami rata-rata $5 \%$ episode serangan per tahun selama kehidupan pasien. Obstruksi katub jantung prostetik dapat disebabkan oleh formasi trombus, pannus ingrowth, atau kombinasi keduanya. Penyebabnya sulit ditentukan dan membutuhkan keahlian khusus dalam mengidentifikasi manifestasi klinis dan pemeriksaan diagnostik berupa echocardiography, termasuk pemeriksaan TTE ${ }^{4}$.

Oleh karena resiko terjadinya komplikasi selama kehamilan pada wanita dengan katub jantung prostetik tergantung pada alat prostetik yang digunakan (jenis dan ukuran), lokasi implantasi dan fungsi katub prostetik, yang dapat mempengaruhi fungsi jantung, gejala klinis yang muncul dan kapasitas fungsional, maka harus dilakukan evaluasi dan konsultasi prekonsepsi yang baik sehingga dapat diketahui fungsi jantung beserta katubnya. Pasien dan keluarga harus diberikan pengertian bahwa komplikasi mayor yang potensial terjadi selama kehamilan termasuk diantaranya adalah gejala klinis dan hemodinamik dapat memburuk, tromboemboli, perdarahan, endokarditis, SVD pada pengguna katub bioprostetik dan anemia hemolitik ${ }^{5,8}$.

Penggunaan antikoagulan dalam kehamilan memiliki keterbatasan dibandingkan dengan wanita tidak hamil. Tentu saja hal ini akan memberikan konsekuensi tersendiri bagi pengguna katub prostetik mekanik. Selama menggunakan katub jantung mekanik, pasien iini menggunakan antikoagulan warfarin $1 \times 2 \mathrm{mg}$ termasuk saat hamil. Pada trimester 1 pasien mengalami abortus iminens yang kemungkinan disebabkan oleh penggunaan warfarin. Disebutkan bahwa pengguna katub jantung prostetik dengan konsumsi warfarin akan menyebabkan abortus sebanyak $26,6 \%$, sedangkan penggunaan heparin sebesar $14,3 \%{ }^{7}$. Warfarin merupakan antikoagulan oral yang diperkenalkan pertama kali pada tahun 1948. Obat ini bekerja dengan mempengaruhi sintesis faktor pembekuan darah tergantung dari vitamin $\mathrm{K}$ seperti faktor pembekuan II, VII, IX dan X dan pembekuan protein 
induced by vitamin $\mathrm{K}$ absent or antagonist (PIVKA) $)^{8,9}$.

Kelebihan penggunaan warfarin adalah karena pemakaiannya mudah, efektif dan murah. Akan tetapi oleh karena mempertimbangkankan dampak yang bisa terjadi pada janin, maka penggunaan warfarin memiliki batasanbatasan tertentu, terutama mengenai penggunaan pada trimester pertama ${ }^{6}$.

Meskipun telah dilaporkan bahwa warfarin merupakan antikoagulan yang bersifat acceptable, namun beberapa peneliti menyarankan untuk menghindari penggunaan warfarin terutama kehamilan trimester pertama karena warfarin diketahui bersifat teratogenik dan dapat melewati plasenta. Namun ada pula pendapat lain yang tetap menggunakan warfarin, yakni dengan menggunakan dosis yang lebih rendah dari $5 \mathrm{mg} / \mathrm{hari}$, meskipun hal ini masih bersifat kontroversial ${ }^{4}$.

Kehamilan pada pasien ini dimonitoring secara berkala dengan menggunakan ultrasonografi pada trimester pertama untuk mendeteksi dini adanya embriopati. Selanjutnya pada kehamilan trimester kedua dan ketiga dilakukan monitoring kesejahteraan janin dengan menggunakan pemeriksaan ultrasonografi dan kardiotokografi. Pada kasus ini tidak didapatkan kelainan kongenital mayor sehingga kehamilan dapat dipertahankan sampai dengan aterm.

Hasil akhirnya dari studi kasus ini tidak didapatkan komplikasi fetus. Pada awal pasien datang, didapatkan ancaman kehamilan berupa abortus imminen. Akan tetapi abortus imminen dapat dicegah sehingga tidak terjadi fetal loss. Disamping itu, meskipun terdapat penatalaksanaan yang tidak sesuai dengan prosedur dimana pada usia kehamilan $6-12$ minggu pasien tetap menggunakan warfarin, namun resiko terjadinya embriopati tidak dijumpai. Hal ini kemungkinan disebabkan oleh karena penggunaan warfarin $4 \mathrm{mg} / \mathrm{hari}$. Disebutkan bahwa penggunaan warfarin $<5 \mathrm{mg} / \mathrm{hari}$ komplikasi fetal sebanyak $15 \%$ dan tidak didapatkan angka kejadian embriopati. Hal ini menunjukkan bahwa ada kemungkinan penggunaan warfarin dosis rendah tidak menimbulkan resiko komplikasi meskipun hal ini masih diperdebatkan ${ }^{6,8}$.

Heparin unfraksional tidak melewati sawar plasenta. Oleh karena itu, resiko embriopati dapat dihindari selama penggunaannya. Akan tetapi heparin dikaitkan dengan adanya komplikasi terhadap maternal jika dibandingkan dengan penggunaan warfarin. Komplikasi yang mungkin terjadi adalah trombositopenia ${ }^{13}$. Kelemahan heparin unfraksional diantaranya adalah memerlukan pemberian secara parenteral dan efek antikoagulan yang lebih rendah dibandingkan derivat koumarin namun lebih tidak bersifat teratogenik ${ }^{6}$.

Penatalaksanaan kehamilan dengan katub jantung prostetik mekanik, harus dilakukan semenjak awal saat seorang wanita mulai menginginkan kehamilan. Harus diberikan edukasi dan pemahaman kepada pasien mengenai konsekuensi pemakaian antikoagulan sepanjang kehamilan, seperti tampak pada Gambar $2^{14}$.

Pada pasien ini, tidak dilakukan konseling pre-konsepsi sebelumnya dikarenakan pada saat pasien datang ke Poli Hamil Rumah Sakit dr. Saiful Anwar Malang pasien sudah dalam kondisi hamil dengan usia $4-6$ minggu. Pasien datang dengan keluhan perut sakit dirasakan seperti haid tetapi tidak didapatkan perdarahan pervaginam. Pasien direncanakan untuk menjalani rawat inap untuk diobservasi lebih lanjut serta dilakukan pemeriksaan kapasitas jantung lebih optimal. Disamping itu, untuk persiapan jika didapatkan komplikasi abortus lebih lanjut berupa perdarahan terkait dengan penggunaan antikoagulan warfarin. Akan tetapi karena penderita menolak, sehingga dilakukan pemeriksaan echokardiogram secara elektif perpoliklinis. Hasil dari 
pemeriksaan tersebut normal, tidak didapatkan trombus.

$$
\text { Echocardiogram lebih }
$$

diutamakan untuk dilakukan saat sebelum kehamilan. Akan tetapi pemeriksaan TTE tetap diperlukan pada saat kehamilan untuk melakukan evaluasi katub prostetik, fungsi ventrikel dan mengukur tekanan pulmoner. Oleh karena adanya peningkatan curah jantung selama kehamilan, maka mean pressure gradient yang melewati prostetik mekanik akan meningkat terutama pada kehamilan trimester kedua dan akan semakin meningkat pada trimester ketiga. Parameter hemodinamik lainnya adalah pemeriksaan diastolic half-time (untuk prostetik katub mitral) dan dimensionless index (ratio antara LV outflow time velocity dibagi dengan peak aortic valve velocity untuk prostesa pada aorta ) harus digunakan untuk menilai fungsi prostesa ${ }^{14}$.

Pemeriksaan TTE harus diulang pada semua wanita hamil dengan katub prostetik yang menunjukkan gejala. Jika didapatkan perubahan status klinis pada pemeriksaan, maka merupakan indikasi untuk dilakukan pemeriksaan echocardiogram untuk menilai perubahan fungsi ventrikel dan hemodinamik katub prostetik. Katub jantung bioprostetik memiliki resiko terjadi degenerasi jaringan (stenosis katub bioprostetik biasanya akan lebih lambat muncul, sedangkan regurgitasi bioprostetik dapat muncul mendadak oleh karena robeknya daun katub pada area yang terjadi kalsifikasi). Sedangkan katub jantung mekanik rawan terjadi stenosis akut atau regurgitasi selama kehamilan oleh karena trombosis katub sehingga membatasi lubang katub atau bahkan menutup. TTE harus dilakukan sebagai pemeriksaan awal oleh karena aliran transvalvular baik aorta maupun mitral dapat direkam pada pemeriksaan ini. TTE juga diperlukan pada kasus yang dicurigai terjadi MR prostetik. Meskipun paparan radiasi sebaiknya dibatasi, fluoroskopi katub mekanik dapat membantu evaluasi gerakan disc. TTE harus dikerjakan pada semua wanita hamil dengan katub jantung prostetik mekanik yang mengalami obstruksi katub prostetik atau mengalami emboli ${ }^{14}$.

Pasien hamil dengan katub jantung mekanik harus dimonitoring di pusat kesehatan tersier dengan dibentuk suatu tim katub jantung yang terdiri dari kardiologis, bedah, anestesiologis dan bagian obstetrik dengan pengalaman cukup terhadap management pasien jantung dengan resiko tinggi.

Wanita dengan katub jantung mekanik memiliki resiko tinggi mengalami komplikasi selama kehamilan. Terdapat resiko tinggi terjadi trombosis katub mekanik oleh karena adanya kondisi hiperkoagulabilitas, terutama pada mereka dengan katub jantung pada mitral. Regimen antikoagulan untuk mencegah trombosis katub harus diketahui secara mendalam terutama mengenai manfat dan resikonya. Trombosis katub dapat menyebabkan gagal jantung berat yang akut dan atau kejadian emboli yang dapat menyebabkan kematian maternal dan fetal. Kejadian trombosis katub selama kehamilan dapat dicegah secara medis dan seringkali membutuhkan operasi emergensi. Oleh sebab itu, perawatan secara terintegrasi dengan membentuk suatu "Tim Katub Jantung" sangat diperlukan ${ }^{15}$.

Dalam studi kasus ini, pada usia kehamilan 6 minggu, pasien telah ditawarkan untuk dilakukan penggantian warfarin dengan pemberian heparin. Namun pasien menolak dengan alasan pemberian heparin harus rawat inap di rumah sakit. Akan tetapi telah diberikan edukasi yang baik mengenai resiko yang mungkin timbul akibat pemberian warfarin pada usia kehamilan 6 minggu. Oleh sebab itu, diputuskan untuk memberikan warfarin dosis rendah yakni 2-4 mg/hari, hal ini didasarkan beberapa studi yang menyebutkan 
bahwa warfarin dosis < $5 \mathrm{mg} / \mathrm{hari}$ memiliki resiko komplikasi fetus yang rendah $^{6,8}$. Bagan penatalaksaan pemberian antikoagulan pada wanita hamil dengan katub jantung prostetik yang direkomendasikan oleh American Heart Association/American College of Cardiology (AHA/ACC) dapat dilihat pada Gambar $4^{14}$.

Terdapat resiko tinggi terjadinya trombosis katub pada pasien dengan katub jantung mekanik akibat adanya kondisi hiperkoagulabilitas selama kehamilan. Semua regimen antikoagulan dapat meningkatkan resiko pada fetus yakni terjadinya abnomalitas fetal, meningkatnya kejadian abortus, dan komplikasi perdarahan (termasuk diantaranya perdarahan retroplasental) sehingga dapat menyebabkan meningkatnya kejadian persalinan prematur dan kematian janin. Akan tetapi, jika tanpa antikoagulan, maka kematian maternal akan meningkat (sampai dengan 5\%) dan terdapat resiko tinggi kejadian tromboembolik (sampai dengan 24\%) dan kejadian trombosis katub. Oleh karena adanya efek fisiologis kehamilan, terdapat perubahan pula terhadap penggunaan antitrombotik. Antikoagulan yang efektif dengan monitoring berkala terhadap kemungkinan terjadinya efek sistemik merupakan hal penting yang harus dilakukan ${ }^{14}$.

\section{KETERBATASAN PENELITIAN}

Studi kasus ini masih memiliki keterbatasan yang dapat dijadikan acuan atau saran guna perbaikan penelitian berikutnya. Keterbatasan tersebut diantaranya adalah penggunaan prosedur tatalaksana yang tidak sesuai dengan yang dianjurkan oleh AHA/ACC tahun 2006 oleh karena semua tindakan yang dilakukan berdasarkan inform choice yang dipilih oleh pasien dan keluarga.

\section{KESIMPULAN}

Telah dilaporkan seorang wanita usia 39 tahun dengan katub jantung prostetik mekanik pada katub mitral dalam terapi antikoagulan warfarin selama kehamilan dan dilanjutkan dengan terapi heparinisasi pada saat menjelang terminasi kehamilan. Disamping itu, penderita juga memiliki riwayat katub trikuspid post anuloplasti dengan De vega Procedure serta memiliki riwayat asma bronkhiale. Hasil akhir dari tatalaksana yang digunakan, didapatkan outcome yang baik terhadap ibu maupun janin. Tidak didapatkan tanda-tanda embriopati akibat penggunaan warfarin pada trimester pertama.

Perlu dilakukan observasi lebih lanjut terhadap outcome bayi untuk mengetahui adanya kelainan yang mungkin timbul pada saat fase tumbuh kembang.

\section{DAFTAR PUSTAKA}

[1] Pieper P.G, A. Balci, A.P. Van Dijk, December 2008, Pregnancy in women with prosthetic heart valves Netherlands Heart, Netherlands Heart Journal, Volume 16, Number 12

[2] Ashour ZA1, Shawky HA, Hassan Hussein M, Outcome of pregnancy in women with mechanical valves Tex Heart Inst J. 2000;27(3):240-5.

[3] Cunningham FG et al.; 2010, Cardiovascular disease. In: William Obstetric. 23rd edition. USA; The McGraw-Hill Companies.1181-207

[4] Hatem A, 2001

[5] Taylor J. 2011, The first ESC guidelines on the management of cardiovascular diseases during pregnancy. Eur Heart J, 32:3055-6

[6] Srivastava AR., Modi P., Sahi S., Niwariya Y., Singh H., Banerjee A., 2007. Anticoagulation for Pregnant Patients with Mechanical Heart Valves. Department of Cardiovascular and Thoracic Surgery, G. B. Pant Hospital, New Delhi, India. Annals of Cardiac Anaesthesia; 10: 95-107

[7] Al-Lawati et al., 2002 
[8] Elkayam U, Bitar F.; 2005, Valvular heart disease and pregnancy part I: native valves. J Am Coll Cardiol, 46:223-30

[9] Wirawan R, 2007, Pemeriksaan laboratorium untuk pemantauan antikoagulan oral. Dalam Rahayu D setiabudy (editor). Hemostasis dan Trombosis. Edisi Ketiga. Balai Penerbitan FKUI. 91-107

[10] Garipidou V.; 2005, Oral Anticoagulation - Past, Present and Future. Haema, 8 (suppl. 1): S62 - S67)

[11] Elkayam U, Bitar F.; 2005, Valvular heart disease and pregnancy: part II: prosthetic valves. J Am Coll Cardiol, 46:403-10

[12] Vitale N, Feo MD, DeSanto LS, et al. 1999, Dose-dependent Foetal Complications of Warfarin in Pregnant Women with Mechanical Heart Valves. J Am Coll Cardiol, 33: 1637-1641

[13] Chan WC, Anand S, Ginsberg JS.; 2000, Anticoagulation of pregnant women with mechanical heart valves. A systematic review of the literature. Arch intern, 160: 191-196

[14] Nishimura et al; 2014 AHA/ACC Guideline for the Management of Patients With Valvular Heart Disease. Journal of the American College of Cardiology by the American Heart Association, Inc., and the American College of Cardiology Foundation Published by Elsevier Inc. Vol. 63, No. 22

[15] Basude S, Hein C, Curtis SL, Clark A, Trinder J; 2012. Low-molecularweight heparin or warfarin for anticoagulation in pregnant women with mechanical heart valves: what are the risks? A retrospective observational study. The Authors BJOG 